\title{
The Research on the Development Problems and Countermeasures of Cross-Border E-Commerce in Liaoning Province
}

\author{
Xiu-dan Huang \\ Liaoning Economic Vocational Technological Institute \\ Liaoning, China
}

\begin{abstract}
The promulgation and implementation of the opinions of the CPC Central Committee and the State Council on the comprehensive revitalization of northeastern China and old industrial bases provided historic opportunities for the development of Liaoning province; the core of development is to realize the transformation and upgrading of economic structure and industrial structure. Then foreign trade, as the main driving force of economic development, will play an indispensable role in the transformation and upgrading, the development of crossborder e-commerce will realize the transformation and upgrading of foreign trade development, and will inject new impetus into foreign trade and even the whole economic development. The main body of cross-border e-commerce in Liaoning province is the small and medium-sized enterprises whose fate is closed related to the research of cross-border ecommerce. The research also exerts an influence onthe upgrading of industrial structure. This paper mainly discusses some problems in the development of cross-border e-commerce in Liaoning province, such as weak brand awareness of enterprises, insufficient application of e-commerce information technology, large gap in talent demand, logistics mode, etc. Through the creation of enterprise advantage brand, establishing a leading multi-polar cross-border e-commerce industry chain, strengthening the application of information technology in crossborder e-commerce, uniting universities, enterprises and the government to participate in the training of mixed talents, improving the efficiency of logistics and others, it is possible to build a comprehensive service platform suitable for the development of cross-border e-commerce in Liaoning province to improve the comprehensive level of cross-border e-commerce. The platform can become the important fulcrum that revitalizes the northeast, offers help for economic development of Liaoning province.
\end{abstract}

Keywords-cross-border e-commerce; economic development; information technology

\section{INTRODUCTION}

Liaoning province is the leader of the old industrial bases in the northeast of China, and the heavy industry products have strongly promoted the development of traditional foreign trade, which is also an important basis for cross-border ecommerce which is the new form of foreign trade. The government of Liaoning province has recognized the importance of cross-border e-commerce in promoting the development of foreign trade. Cross-border e-commerce has been developed in Huludao, Dalian, Jinzhou and other regions. In November 2014, The swimwear cross-border e-commerce pilot was carried out in Huludao. The connectivity was achieved with the unified cross-border trade, retail and export platform of the General Administration of Customs. While vigorously developing cross-border e-commerce, Liaoning province also pays attention to the development of featured cross-border e-commerce platforms. By letting the fastgrowing enterprisesdevelop the e-commerce platform themselves, the group advantages and industrial chain interconnection advantages of the enterprises will drive the development of the whole industry.

At the same time, Liaoning province has encountered some problems while vigorously developing cross-border ecommerce, for example, enterprise brand awareness is weak, e-commerce information technology application is insufficient, talent demand gap is large etc. Enterprises should actively participate in the cross-border e-commerce international market competition, and the government should provide financial support for the development of cross-border e-commerce. Moreover, the perfect trade talent training system should be used to provide talents for the development of cross-border e-commerce business, improve logistics efficiency, establish a credit system of cross-border ecommerce, increase government support, build a comprehensive service platform suitable for the development of cross-border e-commerce in Liaoning province to improve the comprehensive level of cross-border e-commerce.

\section{THE PROBLEMS EXISTING IN THE DEVELOPMENT OF CROSS-BORDER E-COMMERCE IN LIAONING PROVINCE}

\section{A. The enterprise brand awareness is weak}

The brand awareness of cross-border e-commerce enterprises in Liaoning province is not strong. On the basis of the development of cross-border e-commerce business, the products operated cannot form a unique competitive advantage, and the enterprise's brand awareness is poor. We can only attract the customers by the low price in the market competition. 
forming unique advantages of Liaoning province brands on the e-commerce platform. Liaoning province should establish its own superiority project in order to build the superiority brand of enterprises. Besides the government, trading enterprises in Liaoning should also realize that cross-border ecommerce has gradually become an important form of international trade. The enterprises which develop electronic commerce should change the idea, break the fetter of the traditional price war. While developing an e-commerce business, the enterprise's exclusive brand should be created. The professional pre-sales consulting and good after-sales service system can also attract consumers and form a brand competitive advantage. The enterprises should also pay attention to protecting intellectual property to avoid being copied by competitors. Their core technologies, product features and service methods should be reflected with the brand of the enterprises.

\section{B. Strengthening the application of information technology in cross-border e-commerce}

Cross-border e-commerce is a typical example of "inclusive trade" and "digital trade" developed by relying onthe Internet and electronic data application. The application of electronic data is the foundation of this new industry, and it will certainly become the most important foundation of the government industry supervision, service and support. Local governments that wish to develop cross-border e-commerce must invest more in information service platforms for crossborder e-commerce. Just like the large e-commerce platform enterprises, governments can learn to use the platform to collect and process data, and realize the effective support and supervision of cross-border e-commerce industry in the whole region by controlling and mining the application value of data resources [4]. The government of Liaoning should build an open cross-border e-commerce information platform to enable enterprises to follow the dynamics of the international market. At the same time, the advantage products of Liaoning should be introduced in the information platform to provide help for the development of cross-border e-commerce. Finally, the improvement of the application of cross-border e-commerce information technology also needs to strengthen the technology innovation. Combining with the development trend of cross-border e-commerce trade, the higher colleges should optimize the existing e-commerce platform page, improve the access speed, narrow the gap with the cross-border ecommerce platform in developed countries, optimize the customer experience, to make the cross-border e-commerce development of Liaoning province effectively dock with the international advanced level.

\section{Uniting the higher colleges, enterprises and the governments in training the mixed talents}

Compared with the international trade and e-commerce, cross-border e-commerce talents need to face customers from all over the world, which requires them to master different languages, history, culture and customs of different countries. At the same time, they should also master the knowledge of computer networks, online payment, logistics and distribution related to e-commerce. The cross-border e-commerce merchants should be high compound talents. Therefore, 
3) Strengthening the construction of logistics information

In January 2013, the Ministry of Industry and Information Technology of the People's Republic of China issued The Guidance on Promoting Logistics Informatization, pointing out that the construction of logistics informatization should be accelerated, which is good for the continuous improvement of China's infrastructure and the further development of crossborder e-commerce. For example, relying on the public information service platform of e-commerce in Binhai hightech zone, Tianjin has built a one-stop service center for crossborder e-commerce, which provides services such as agent operation, marketing, customer service, logistics warehousing and technical support for cross-border e-commerce enterprises.

\section{CONCLUSION}

Liaoning province is the gateway of northeast China and has inherent advantages in developing cross-border ecommerce; the transitional environment of the new policy on cross-border e-commerce has provided Liaoning province with the acquired supports for developing the cross-border ecommerce. Enterprises should actively participate in the crossborder e-commerce international market competition; the governments should provide financial support for the development of cross-border e-commerce business. At the same time, the perfect trade talent training system is used to provide talent support for the development of cross-border ecommerce business, improve logistics efficiency, establish a credit system for cross-border e-commerce, increase the government support to build a comprehensive service platform suitable for the development of cross-border e-commerce in Liaoning province, so as to improve the comprehensive level of cross-border e-commerce.

Although there are still many difficulties in developing cross-border e-commerce, opportunities always outweigh challenges. As long as the development direction is right and the strategy is appropriate, the cross-border e-commerce will surely become an important fulcrum to revive the economy of the whole province, or even the revitalization of the northeast of China.

\section{REFERENCES}

[1] Jiang Yong. The Development of Cross-Border E-Commerce and its Application in Small and Medium-Sized Foreign Trade Enterprises, Business Theory of China 2016.12

[2] Zhang Chunfeng. Feng Chunshu, The Analysis on the Development Path of Cross-Border E-Commerce in Liaoning, The Economy of Liaoning2016.3

[3] Wang Huimin. The Transformation and Upgrading of Cross-Border ECommerce and International Trade.2014.10

[4] Luo Min, The Cross-Border E-Commerce Helps to Transform Guangdong's Foreign Trade, China Economic Herald 2015

[5] Tang Bingyong, et al. China Cross Border E-Commerce Development Report (2014-2015) [M]. Beijing: Chemical Industry Press, 2016

[6] Fan Wenjing. Development of Cross-Border E-Commerce and Transformation of China's Foreign Trade Model [J]. Foreign trade and economic cooperation, 2015, (1). 